\title{
Effect of Debt to Equity Ratio and Return on Assets on Earnings per Share with Firm Value as a Moderating Variable in Various Industrial Sub-Sector Manufacturing Companies Indonesia
}

\section{Citra Larasati $i^{\bowtie}$ \\ Abdul Rivai' ${ }^{2}$ \\ Suharto $^{3}$ (D)}

${ }^{1,2, s}$ Universita Krisnadwipayana, Campus Unkris Jatiwaringin Jat CM Jakarta, Indonesia. Email:queensyauqina07@gmail.com Tel: +6281387443184

'Email:abdulrivai@unkris.ac.id Tel: +62817847600

'Email:suharto@unkris.ac.id Tel:+6281283291784

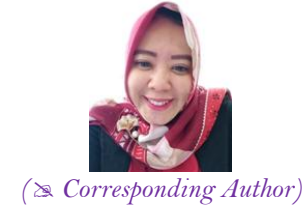

Check for updates

\section{Abstract}

This study aims to examine and determine the effect of debt to equity ratio and return on assets on earnings per share with firm value as a moderating variable in various industrial sub-sector manufacturing companies listed on the Indonesia Stock Exchange for the period 2016-2018. The population in this study was 45 companies in various industrial sub-sectors listed on the Indonesia Stock Exchange (BEI) during the 2016 - 2018 period. The sample is part of the number and characteristics of the population. The sampling technique used in this research was purposive sampling. The data analysis technique used path analysis. The results showed that the Debt To Equity Ratio (DER) had a significant effect on Earning Per Share, meaning that partially the Debt to Equity Ratio (DER) had an effect on Earning Per Share (EPS). Return On Asset (ROA) affects Earning Per Share (EPS), which means that partially, Return On Asset (ROA) affects Earning Per Share (EPS). Price to Book Value $(\mathrm{PBV})$ as a moderating variable is proven to be able to strengthen the effect of Debt to Equity Ratio (DER) on Earning Per Share, this shows that Price to Book Value (PBV) moderates the Debt to Equity Ratio (DER) against Earning Per Share (EPS). Price to Book Value (PBV) as a moderating variable is proven to be able to strengthen the effect of Return On Assets (ROA) on Earning Per Share (EPS), this shows that Price to Book Value (PBV) moderates the Return On Asset relationship. (ROA) against Earning Per Share (EPS).

Keywords: Debt to equity ratio, Return on asset, Earning per share, Price to book value, Various industrial sub-sectors, Indonesia stock exchange.

JEL Classification: B27, H54, L60.

\section{Introduction}

Indonesia is ready to welcome the era of industrial revolution 4.0 which is targeted to have an impact on the manufacturing industry. When viewed from the national Gross Domestic Product (GDP), the manufacturing industry has consistently been the largest contributor to the national Gross Domestic Product (GDP), which was recorded at $19.83 \%$ in the second quarter of 2018 . The rapid growth rate in the national industry is a multiplier effect and high investment in this sector. As of 2010, the trend of investment in the industrial sector in Indonesia has continued to increase even though it was restrained by the financial crisis in 2008. If we take it further back, the growth of the manufacturing industry in the Indonesian economy has gradually increased.

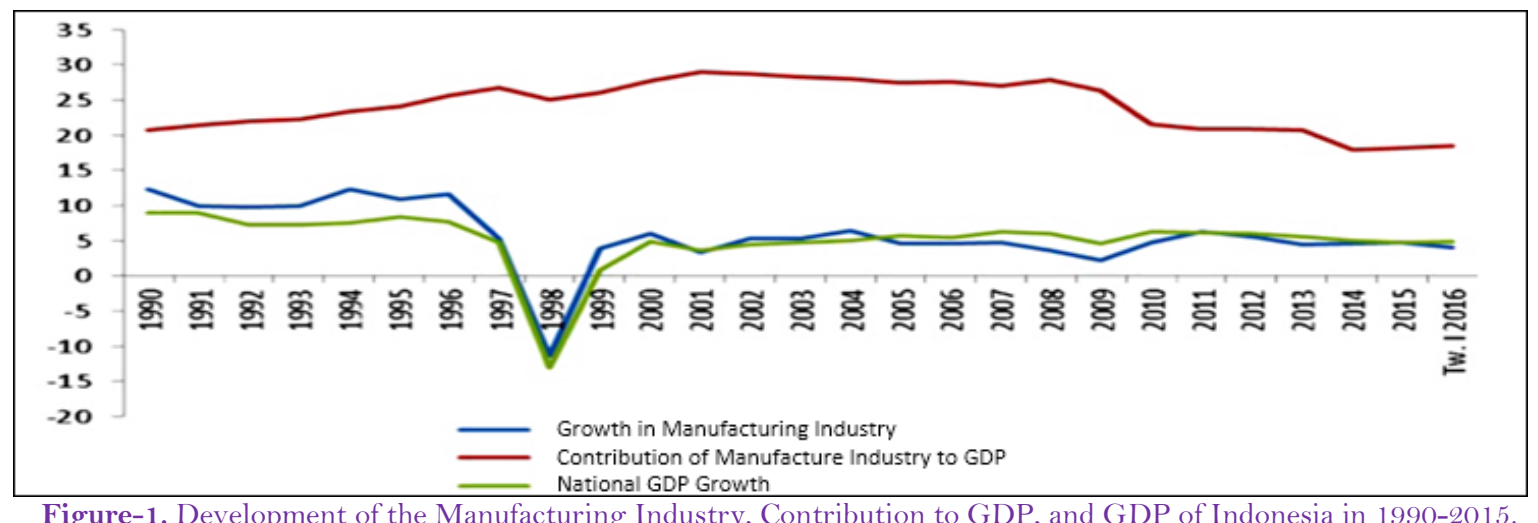

Source: BPS, 2015

In the era of industrial revolution 4.0, which certainly requires a commitment to work together through the implementation of strategic regional programs that bring economic prosperity. As well as to share policies, experiences, technology, knowledge, and best practices related to the development of the manufacturing sector and the implementation of industry 4.O. The Minister of Industry stated that he believed that the transformation of industry 4.0 would lead to a new business model for the globally competitive manufacturing industry. The 
manufacturing industry sector is stable and is one of the pillars of the country's economy amidst the uncertainty of the world economy with a positive growth rate.

The manufacturing industry creates added value which means production or products produced by various companies in the manufacturing sector, such as food, beverages, automotive textiles, pharmaceuticals, electronics, and so on. If the processing is carried out properly and optimally, all the basic ingredients processed in the manufacturing industry can create added value to the resulting product. The more variety and product innovation that is produced, the greater the potential for development. Especially considering that Indonesia has abundant natural resources so that it can be used as a spur to increase the growth of the industrial sector in Indonesia, especially in the manufacturing industry sector.

Behind the increasing economic growth in Indonesia through the manufacturing industry, it is necessary to encourage investment in terms of investment as well. This investment will create an attractive and conducive climate in Indonesia. So that domestic and foreign investors are interested in investing their shares in Indonesia. One of the securities used to invest in stocks. Shares are a sign of someone's participation or ownership in a company (Lukman \& Solihin, 2018). In general, investors will be interested in investing (stocks) if the company can provide the return they expect.

The following is a table of the movement of the manufacturing sector stock price index on the Indonesia Stock Exchange from 2012 to 2015.

\begin{tabular}{|c|c|c|c|}
\hline Year & Basic Industry & Miscellaneous Industry & Consumer Goods \\
\hline 2012 & 526,551 & $1.336,52$ & $1.565,88$ \\
\hline 2013 & 480,744 & $1.205,01$ & $1.782,09$ \\
\hline 2014 & 543,674 & $1.307,07$ & $2.042,25$ \\
\hline 2015 & 407,839 & $1.057,28$ & $2.064,91$ \\
\hline 2015 & 538,189 & $1.370,63$ & $2.324,28$ \\
\hline Average & 499,40 & $1.255,30$ & $1.955,88$ \\
\hline
\end{tabular}

From Table 1. It can be seen that the Consumer Goods sub-sector has the highest average stock price index compared to the stock price index of other manufacturing sub-sectors, namely Rp.1,955.88. Meanwhile, the lowest in the Basic Industry sub-sector. However, when viewed from Figure 1, the manufacturing sector experienced fluctuating data and experienced a significant decline in 2015 and again rose in 2015.

To strengthen the growth of the business world, one of which is in manufacturing companies. Sources of funding for the development of the business sector that can be sought from internal funds and external funds, with limited internal funds, companies can seek additional alternatives to external funds, namely through loans and selling securities through the capital market. Therefore, the existence of the capital market is very profitable. for the company. A capital market is a meeting place for those who have funds and those who need funds. The capital market has various choices of sources of funds for investors as well as increasing investment.

Investing in shares in the capital market is very profitable for investors. By investing in the capital market, investors will get benefits in the form of dividends and capital gains. The amount of dividend distribution is strongly influenced by the number of earnings per share or earnings per share. An investor will invest their funds because they are interested in the company's performance. For this reason, investors need to carry out fundamental analysis, namely analysis that focuses on financial ratios and events that directly or indirectly affect the company's financial performance (Tandelilin, 2010). Financial ratios that can be used include Earning Per Share (EPS), Debt to Equity Ratio (DER), Return on Assets (ROA), and Price to Book Value (PBV).

Earning Per Share is one of the things that attracts investors to decide on investing their funds for the company. If the profit generated by each share in circulation is so good, then the welfare of shareholders can be guaranteed by looking at dividend payments at the end of each year the company operates. A company can be said to have maximized company value if the earnings per share (EPS) obtained continue to experience a high increase in EPS, then the company's performance will be better and can show investors about the company's prospects better (Kukuh, 2015) which states that earnings per share (EPS) affects firm value.

Debt policy is a company policy on how far a company uses debt financing. With debt, the higher the proportion of debt, the higher the share price of the company (Mardiyanti, 2012). Debt policy needs to be managed because too high can reduce the company's value (Perdana, 2012). The debt policy itself is measured by the Debt to Equity Ratio (DER). However, at a certain point, an increase in debt will reduce the value of the company because the benefits obtained from the use of debt are smaller than the costs incurred.

One of the ratios used to measure profitability is ROA (Return on Assets). ROA is used to measure the company's ability to generate profits by utilizing its assets. ROA is the ratio between net income after tax and total assets. The reason for using the ROA variable in this study is because ROA has many advantages. One of them is that ROA can measure the overall efficiency of the use of capital, which is sensitive to everything that affects the condition of the company (Mardiasari, 2012).

Company value is one of the most important things that investors should pay attention to when making investment decisions in a company. High company value is the desire of company owners because a high value indicates the prosperity of shareholders is also high. This is what investors want in investing their funds in a company.

The company's investment opportunity can be proxied by the Price to Book Value ratio. The price ratio or book value is a valuation ratio that investors use to compare the price per share with its book value (shareholder's equity). The Price to Book Value can be a determining indicator of the high and low investment opportunities of a company. Companies usually tend to buy stocks when the Price to Book Value is low in the hope that the stock price can increase at any time. While companies tend to hold cash in small amounts when the Price to Book Value is high because the company's stock price is already high or reaches a maximum amount, then the investment opportunity is low.

Based on the PBV ratio, it can be seen that the company value is good when the PBV value is above one, that is, 
the market value is greater than the company's book value. The higher the PBV value, the better the company value. Conversely, if PBV is below one, it reflects the company's value is not good. So that investors' perceptions of the company are also not good, because the PBV value below one illustrates the company's selling price is lower than the company's book value.

Table-2. Value of DER, ROA, EPS, and PBV in 2012-2016 the five largest manufacturing companies in Indonesia.

\begin{tabular}{|c|c|c|c|c|c|}
\hline Company Name & Years & $\operatorname{Pbv}(\mathrm{X})$ & $\operatorname{Der}(\mathrm{X})$ & Eps (Rp) & Roa (\%) \\
\hline \multirow{5}{*}{ PT. Gudang Garam, Tbk } & 2012 & 4,07 & 0,56 & 2086,06 & 9,8 \\
\hline & 2013 & 2,75 & 0,73 & 2249,76 & 8,63 \\
\hline & 2014 & 3,66 & 0,75 & 2790,76 & 9,27 \\
\hline & 2015 & 2,78 & 0,67 & 3344,78 & 10,16 \\
\hline & 2016 & 3,27 & 0,59 & 3470,26 & 10,6 \\
\hline \multirow{5}{*}{ PT. Indofood Sukses Makmur, Tbk } & 2012 & 1,50 & 0,74 & 371,41 & 8,06 \\
\hline & 2013 & 1,51 & 1,04 & 285,16 & 4,38 \\
\hline & 2014 & 1,45 & 1,08 & 442,50 & 5,99 \\
\hline & 2015 & 1,05 & 1,13 & 338,02 & 4,04 \\
\hline & 2016 & 1,55 & 0,87 & 472,02 & 6,411 \\
\hline \multirow{5}{*}{ PT. Kalbe Farma, Tbk } & 2012 & 7,30 & 0,28 & 28,45 & 18,85 \\
\hline & 2013 & 6,89 & 0,33 & 37,80 & 17,41 \\
\hline & 2014 & 9,30 & 0,27 & 44,05 & 17,07 \\
\hline & 2015 & 5,66 & 0,25 & 42,76 & 15,02 \\
\hline & 2016 & 6,01 & 0,22 & 49,06 & 15,44 \\
\hline \multirow{5}{*}{ PT. Semen Indonesia (Persero), Tbk } & 2012 & 5,18 & 0,46 & 817,20 & 18,54 \\
\hline & 2013 & 3,85 & 0,41 & 905,37 & 17,39 \\
\hline & 2014 & 4,09 & 0,37 & 938,35 & 16,24 \\
\hline & 2015 & 2,46 & 0,39 & 762,28 & 11,86 \\
\hline & 2016 & 1,91 & 0,45 & 762,30 & 10,25 \\
\hline \multirow{5}{*}{ PT. Unilever Indonesia, Tbk } & 2012 & 40,09 & 2,02 & 634,24 & 40,38 \\
\hline & 2013 & 46,63 & 2,14 & 701,52 & 71,51 \\
\hline & 2014 & 45,03 & 2,11 & 752,10 & 40,18 \\
\hline & 2015 & 58,48 & 2,26 & 766,95 & 37,2 \\
\hline & 2016 & 46,67 & 2,56 & 837,57 & 38,16 \\
\hline
\end{tabular}

When viewed from Table 2, at PT Gudang Garam, Tbk. PBV has increased and decreased fluctuating while DER has decreased in 2015 by 0.08, ROA has decreased in 2013 and then increased again until 2016. EPS has increased from 2012 to 2015. At PT Indofood Sukses Makmur, Tbk, PBV has decreased in 2014 by 0.06 and 2015 by 0.4, while DER has decreased in 2015 by 0.26, ROA, and EPS have fluctuated increases and decreases. At PT Kalbe Farma, Tbk, PBV has fluctuated increases and decreases, while DER continues to decline from 2014 to 2015 , ROA has decreased each year, EPS has decreased in 2015 by 1.29. At PT Semen Indonesia (Persero), Tbk PBV there has been a fluctuating increase and decrease while DER has decreased from 2013 to 2015 and increased again until 2015, ROA has decreased every year, EPS has decreased from 2015. At PT Unilever Indonesia, Tbk, PBV and DER have fluctuated increases and decreases, ROA has increased in 2013 then decreased again until 2016, while EPS has increased from 2012 to 2015.

Substantially, a high EPS indicates that ROA is high as well as firm value. ROA is an important indicator in determining earnings growth. On the other hand, the higher use of debt will cause lower EPS and corporate value. The higher the debt, the higher the interest expense borne by the company and can reduce EPS. However, based on the observations that the author has made on certain manufacturing companies that have gone public, which are listed in Table 1 and 2 , there is a phenomenon that is somewhat different from its substance. This phenomenon illustrates that in certain companies, an increase in DER and a decrease in ROA increases EPS and vice versa, a decrease in DER and an increase in ROA decreases EPS. Meanwhile, in other companies, when the DER decreases, EPS tends to be constant and in other companies too, when ROA tends to be constant, EPS fluctuates instead.

\section{Literature Review}

\subsection{Financial Ratios}

Company performance is a description of the financial condition of a company which is analyzed with financial analysis so that it can be seen about the good and bad financial condition of a company that reflects work performance in a certain period (Fahmi, 2015). A company can be said to be successful if it has achieved the standards and goals that have been set. Many financial performance measurement techniques can be used for financial statement analysis and in comparison with other companies. Financial performance is often measured through financial ratios with a focus on measuring different indicators. Types of financial ratios according to (Fahmi, 2015) financial ratios can be grouped into six types, namely:

a. Liquidity ratio, namely the ability of a company to meet its short-term obligations promptly. This ratio is divided into the current ratio, quick ratio (acid test ratio), net working capital ratio, cash flow liquidity ratio.

b. The leverage ratio is a measure of how much the company is financed by debt. Financial managers are required to manage the leverage ratio properly so that they can balance high returns with low levels of risk. The size of this ratio depends on the loans the company has, in addition to its assets (capital). In general, there are eight Leverage ratios (Kasmir, 2016) namely Debt to Total Assets, Debt to Equity Ratio, Times Interest Earned, Cash Flow Coverage, Long-Term Debt to Total Capitalization, Fixed Charge Coverage, and Cash Flow Adequacy.

c. The activity ratio is a ratio that describes the extent to which a company uses its resources to support the company's activities, where the use of this activity is carried out maximally to obtain maximum results. In general, there are four activity ratios (Kasmir, 2016) namely Inventory Turnover, Day Sales Outstanding, Fixed Assets Turnover, Total Assets Turnover, Long Term Assets Turnover. 
d. Profitability Ratios measure the effectiveness of management as a whole aimed at the size of the level of profits obtained concerning sales or investment. The better the profitability ratio, the better it describes the company's high profitability. In general, there are four profitability ratios (Kasmir, 2016) namely Gross Profit Margin, Net Profit Margin, Return On Investment, and Return On Equity.

e. Growth Ratio, which is a ratio that measures how much the company's ability to maintain its position in the industry and general economic development. This growth ratio is commonly seen from various aspects, namely in terms of sales, Earning after Tax (EAT), earnings per share, dividends per share, and market price per share.

f. Market Value Ratio, namely the ratio that describes the conditions that occur in the market. This ratio can provide an understanding of the management of the company on the conditions of implementation that will be implemented and its impact in the future.

\subsection{Earning per Share}

According to Fahmi (2011) Earning per share or income per share is a form of giving benefits to shareholders from each share they own. Earning per share (EPS) is a ratio that reflects the company's ability to generate profits for each share outstanding (Watung \& Ilat, 2015). Earnings per Share (EPS) or income per share is a form of giving profits to shareholders from each share they own (Fahmi, 2011). Meanwhile, according to Tandelilin (2010) EPS is net income that is ready to be distributed to shareholders divided by the number of company shares. According to Darmadji and Fakhruddin (2012) defines Earning Per Share (EPS) as follows: "Earning Per Share (EPS) is a ratio that reflects the company's ability to generate profits for each outstanding share." According to Kasmir (2014) EPS is also known as the book value ratio, which is a ratio to measure the success of management in achieving benefits for shareholders. EPS describes the amount of rupiah obtained for each common share or net income per share of common stock (Retnowati, 2012).

Earnings per Share (EPS) is usually a concern of shareholders in general or prospective shareholders and management. EPS shows the amount of money generated (return) from each share. The greater the EPS value, the greater the profit received by shareholders. An investor buys and maintains stock in a company in the hope of obtaining dividends or capital gains. Profit is usually the basis for determining future dividend payments and stock price increases. Therefore, shareholders are usually interested in the EPS figures that companies report.

According to Brigham and Houston (2010) the factors that cause the increase and decrease in Earning Per Share (EPS) are:

1. Factors causing an increase in Earning Per Share (EPS):

- Net income increased and the number of ordinary shares outstanding remained constant.

- Fixed net income and the number of ordinary shares outstanding decreased.

- Net income increases and the number of ordinary shares outstanding decreases.

- The percentage increase in net income is greater than the percentage increase in the number of ordinary shares outstanding.

- The percentage decrease in the number of ordinary shares outstanding is greater than the percentage decrease in net income.

2. While the decline in Earning Per Share (EPS) can be caused by:

- Fixed net income and the number of ordinary shares outstanding increased

- Net income decreased and the number of ordinary shares outstanding remained constant.

- Net income decreased and the number of ordinary shares outstanding increased.

- The percentage decrease in net income is greater than the percentage decrease in the number of ordinary shares outstanding.

- The percentage increase in the number of ordinary shares outstanding is greater than the percentage increase in net income.

So for a company, the value of earnings per share will increase if the percentage increase in net income is greater than the percentage increase in the number of ordinary shares outstanding, and vice versa.

\subsection{Debt to Equity Ratio}

Debt to Equity Ratio (DER) is a measure used in analyzing financial statements to show the amount of collateral available to creditors (Fahmi, 2015). Debt to Equity Ratio (DER) is one of the ratios included in the leverage ratio. The leverage ratio describes the company's ability to meet all liabilities with the assets it owns. Given that the leverage ratio describes the company's liabilities, the greater the leverage ratio of a company, the greater the company's burden to pay the principal debt and interest costs, which means the greater the risk faced by the company (Simatupang, 2010).

The definition of Debt to equity ratio according to Darsono and Ashari (2010) namely: Debt to Equity Ratio (DER) is one of the leverage or solvency ratios. The solvency ratio is the ratio to determine the company's ability to pay its obligations if the company is liquidated. This ratio is also known as the leverage ratio, which assesses the company's limits on borrowing money. According to Sugiyono (2009) states that: This ratio shows the ratio of debt and capital. This ratio is one of the important ratios because it relates to the problem of trading on equity, which can have a positive and negative impact on the profitability of the company's capital.

From the definition of DER above, it is concluded that DER is a ratio used to measure a company's ability to finance its short-term and long-term debt. This ratio is sought by comparing all debt, including current debt, and total equity. The use of the Debt to Equity Ratio (DER) is to find out every rupiah of own capital that is used as collateral for a debt. So, it can be concluded that the Debt to Equity Ratio (DER) shows how the company's ability to use existing capital to fulfill its obligations.

\subsection{Return on Assets}

Return On Asset (ROA) analysis or often translated into Indonesian as Economic Profitability measures a company's ability to generate profits in the past. This analysis can then be projected into the future to see the company's ability to generate profits in the future. According to Kasmir (2012) the definition of Return On Assets 
(ROA) is as follows: "ROA is a ratio that shows the results (return) on the total assets used in the company. Also, ROA provides a better measure of the company's profitability because it shows the effectiveness of management in using assets to generate income. Meanwhile, according to Fahmi (2012) ROA is a ratio used to see to what extent the investment that has been invested can provide returns after expected returns based on assets owned.

This ratio is used to measure the ability of company management to gain overall profit (profit). So, seen from the above definitions, it can be concluded that Return On Assets (ROA) is a measurement tool used to measure management's ability to generate profits using company assets. ROA is the ratio that companies use in calculating returns on the use of several assets by the company (Horne \& Wachowicz, 2012). According to Kasmir (2016) Return On Assets (ROA) is a ratio that shows the return on the total assets used by the company.

\subsection{The Value of the Company}

Price to Book Value (PBV) will be used in this study as a proxy for firm value. The ratio of the stock price to the company's book value or Price to Book Value (PBV), shows the level of the company's ability to create value relative to the amount of invested capital. A high PBV reflects a high share price compared to book value per share. The market price ratio to book value is the division of the market price per share by the book value per share. This ratio compares the market value of the investment in the company with its costs. A value of less than 1 means that the company fails to create value for its shareholders (Rahardjo, 2009).

\section{Research Methods}

\subsection{Time and Location of Research}

In conducting this research, the research location chosen by the researcher was in various Industry Sub-Sector Manufacturing companies that were listed on the Indonesia Stock Exchange (IDX) during the period 2016-2018.

\subsection{Research Design}

The research design used in this research is descriptive analysis and verification methods. Descriptive analysis is carried out to obtain a description or information about the variables studied and observed based on the statistical data obtained. The descriptive method in this study is intended to determine the development of Debt to Equity Ratio and Return on Assets to Earning per Share with Firm Value as the moderating variable. Meanwhile, verification analysis is carried out to test the hypothesis using a statistical test tool, namely the multiple regression method. The verification method in this study aims to determine the effect of Debt to Equity Ratio and Return on Assets on Earning per Share with Firm Value as a moderating variable.

This phenomenon can be designed through the following mathematical functions:

\subsubsection{Model 1}

The role of the variable X1 Debt to Equity Ratio (DER), to the variable Y Earning press Share (EPS) with Firm Value (PBV) as the moderating variable X3 can be formulated by:1) $\mathrm{EPS}=\alpha+\beta 1 \mathrm{DER}+\mathrm{e}$

2) $\mathrm{EPS}=\alpha+\beta 1 \mathrm{DER}+\beta 2 \mathrm{NP}+\beta 3 \mathrm{DER} . \mathrm{NP}$

This analysis can be described as follows:

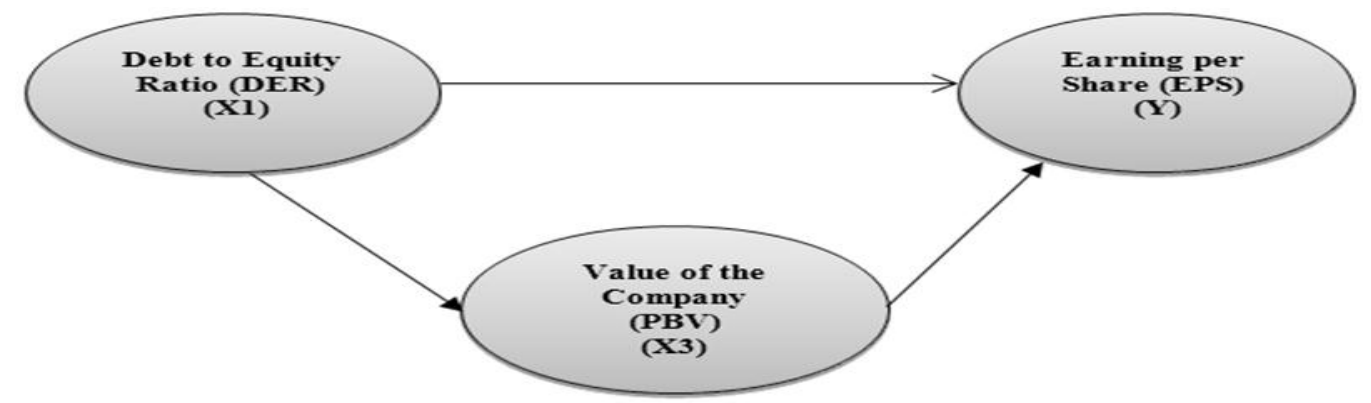

Figure-2. Regression relationship model with the first moderating variable. Source: Processing results, 2020

\subsubsection{Model 2}

The role between the variable X2 Return on Assets (ROA), on the variable Y Earning press Share (EPS) with Firm Value (PBV) as the moderating variable $\mathrm{X} 3$ can be formulated by:1) $\mathrm{EPS}=\alpha+\beta 1 \mathrm{ROA}+\mathrm{e}$

2) $\mathrm{EPS}=\alpha+\beta 1 \mathrm{ROA}+\beta 2 \mathrm{NP}+\beta 3$ ROA.NP

This analysis can be described as follows:

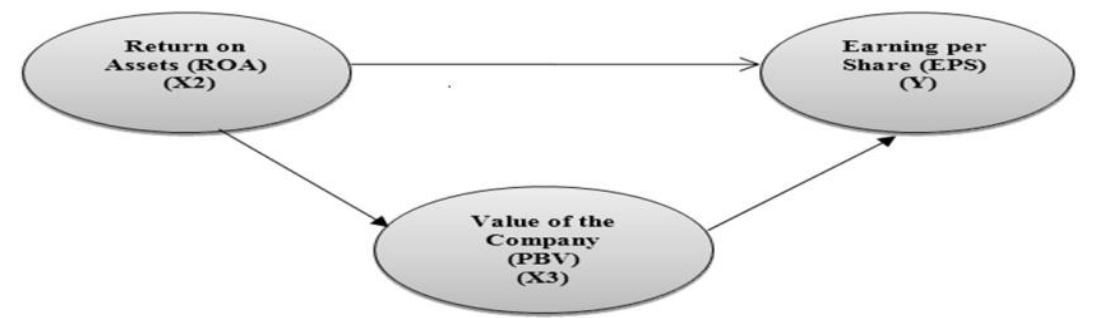

Figure-3. Regression relationship model with the second moderating variable.

\subsection{Population and Sample}

Sugiyono (2009) states that the population is a generalization area consisting of objects/subjects that have certain qualities and characteristics that are determined by the researcher to be studied and then draw conclusions. 
The population in this study was 45 companies in various industrial sub-sectors listed on the Indonesia Stock Exchange (BEI) during the 2016 - 2018 period. The sample is part of the number and characteristics of the population. The sampling technique is a sampling technique (Sugiyono, 2009). The sampling technique used in this research was purposive sampling. The data analysis technique used path analysis.

\section{Research Results and Discussion}

\subsection{Moderated Regression Analysis Equations}

Moderated Regression Analysis Equation is used to predict and test the changes that occur in Earning Per Share (EPS) which can be explained by two independent variables and reinforced or amplified by one moderating variable.

\subsubsection{Moderated Regression Analysis Equations for DER (X1), PBV (X3), and EPS (Y)}

To determine the effect of Debt to Equity Ratio (DER) on Earning Per Share (EPS) which is moderated by Firm Value (PBV), analysis calculations using Moderated Regression Analysis (MRA) are performed. The results of calculations using SPSS obtained regression coefficients and constant values as in the following table:

Table-3. Regression coefficient results DER (X1), PBV (X3), and EPS (Y).

\begin{tabular}{|c|c|c|c|c|c|c|}
\hline & \multirow{2}{*}{ Model } & \multicolumn{2}{|c|}{ Unstandardized Coefficients } & \multirow{2}{*}{$\begin{array}{c}\text { Standardized Coefficients } \\
\text { Beta }\end{array}$} & \multirow[t]{2}{*}{$t$} & \multirow[t]{2}{*}{ Sig. } \\
\hline & & B & Std. Error & & & \\
\hline \multirow{4}{*}{1} & (Constant) & 169.070 & 212.329 & & .796 & .432 \\
\hline & DER & 2.876 & 61.535 & .013 & .047 & .963 \\
\hline & PBV & 16.460 & 43.738 & .113 & .376 & .709 \\
\hline & DER*PBV & 11.079 & 15.490 & .255 & .715 & .480 \\
\hline
\end{tabular}

The regression equation that explains the effect of Debt to Equity Ratio (DER) on Earning Per Share (EPS) moderated by Firm Value (PBV) is:

$$
\mathrm{Y}=169,070+2,876 \mathrm{X} 1+16,460 \mathrm{X} 3+11,079 \mathrm{X} 1 . \mathrm{X} 3
$$

The Debt to Equity Ratio (DER) variable regression coefficient of 169,070 explains the magnitude of the change in the score of Earning Per Share (EPS) because of the effect of Debt to Equity Ratio (DER) on Earning Per Share (EPS). A positive sign indicates the direction of the relationship is directly proportional (inline). So when there is an increase in the score of the Debt to Equity Ratio (DER) variable, the Earning Per Share (EPS) score will increase by 169,070, assuming that other factors are constant (unchanged). So the more appropriate the Debt to Equity Ratio (DER), the EPS will increase (better). The variable regression coefficient (X3) of 2,876 shows the magnitude of the change in Earning Per Share (EPS) due to the influence of the variable Firm Value (PBV) on Earning Per Share (EPS). A positive sign indicates the direction of the relationship that is directly proportional (inline). So every time there is an increase in one unit variable score (X3), the EPS will increase by 2,876 assuming the other factors are constant (unchanged). So the higher (X3), the Earning Per Share (EPS) will increase (better). The regression coefficient of the moderating variable X1X3 (interaction X1X3) which is the interaction between the Debt to Equity Ratio (DER) and PBV is obtained as positive. So it can be explained that PBV strengthens the effect of Debt to Equity Ratio (DER) on Earning Per Share (EPS).

\subsubsection{Equation of Moderated Regression Analysis of ROA (X2), PBV (X3), and $\operatorname{EPS}(\mathcal{Y})$}

To determine the effect of Return On Asset (ROA) and Firm Value (PBV) on Earning Per Share (EPS), which is moderated by Firm Value (PBV), analysis is calculated using Moderated Regression Analysis (MRA). The results of calculations using SPSS obtained regression coefficients and constant values as in the following table:

\begin{tabular}{|c|c|c|c|c|c|c|}
\hline & \multirow[t]{2}{*}{ Model } & \multicolumn{2}{|c|}{ Unstandardized Coefficients } & \multirow{2}{*}{$\begin{array}{c}\text { Standardized Coefficients } \\
\text { Beta }\end{array}$} & \multirow[t]{2}{*}{$\bar{T}$} & \multirow[t]{2}{*}{ Sig. } \\
\hline & & B & Std. Error & & & \\
\hline \multirow{4}{*}{1} & (Constant) & 160.338 & 139.370 & & 1.150 & .259 \\
\hline & ROA & 41.772 & 21.743 & .754 & 1.921 & .064 \\
\hline & PBV & 23.441 & 26.552 & .160 & .883 & .384 \\
\hline & ROA*PBV & -2.367 & 2.372 & -.408 & -.998 & .326 \\
\hline
\end{tabular}

The regression equation that explains the effect of Return On Assets (ROA) and Firm Value (PBV) on Earning Per Share (EPS) is moderated by Firm Value (PBV):

$$
\mathrm{Y}=160,338+41,772 \mathrm{X} 2+23,441 \mathrm{X} 3+-2,367 \mathrm{X} 2 . \mathrm{X} 3
$$

The regression coefficient of the Return On Asset (ROA) (X2) variable of 160,338 explains the magnitude of the change in the score of Earning Per Share (EPS) because of the effect of Return On Asset (ROA) on Earning Per Share (EPS). A positive sign indicates the direction of the relationship is directly proportional. So when there is an increase in Return On Asset (ROA), the score of Earning Per Share (EPS) will increase by 160,338 assuming the other factors are constant (unchanged). So the higher the Return On Asset (ROA), the better the Earning Per Share (EPS).

The regression coefficient of Firm Value (PBV) (X3) is 23,441 indicating the magnitude of changes in Earning Per Share (EPS) (Y) due to the influence of the Firm Value (PBV) variable on Earning Per Share (EPS). A positive sign indicates the direction of the relationship that is directly proportional (inline). So every time there is an increase in one unit score of the PBV variable (X3), Earning Per Share (EPS) will increase by 23,441 assuming the other factors are constant (unchanged). So the higher (X3), the Earning Per Share (EPS) will increase (better). The regression coefficient of the moderating variable X2X3 (interaction X2X3) which is the interaction between Return 
on Assets (ROA) and PBV is obtained as a negative sign. So it can be explained that PBV does not strengthen the effect of Return On Assets (ROA) on Earning Per Share (EPS).

\subsection{Hypothesis Test}

\subsubsection{Hypothesis Testing the Effect of DER (X1), PBV (X3) on EPS (Y)}

The hypothesis test used to test the presence or absence of influence is the t-test. Determination of test results (acceptance/rejection of Ho) can be done by comparing $t$ count with $t$ table or can also be seen from its significant value. From the $t$ table, the $t$ table value for $\alpha=0.05$ and degrees of freedom $(\mathrm{DB})=35-2-1=32$ on the two-party test is 2.036. The t-test results can be seen in the following table:

Table-5. The results of the t-test X1, X3 on Y

\begin{tabular}{|c|c|c|c|c|c|c|}
\hline \multirow{2}{*}{\multicolumn{2}{|c|}{ Model }} & \multicolumn{2}{|c|}{ Unstandardized Coefficients } & \multirow{2}{*}{$\begin{array}{c}\text { Standardized Coefficients } \\
\text { Beta }\end{array}$} & \multirow[t]{2}{*}{$\bar{t}$} & \multirow[t]{2}{*}{ Sig. } \\
\hline & & B & Std. Error & & & \\
\hline \multirow{4}{*}{1} & $($ Constant $)$ & 169.070 & 212.329 & & 2.796 & .000 \\
\hline & DER & 2.876 & 61.535 & .013 & 3.047 & .033 \\
\hline & PBV & 16.460 & 43.738 & .113 & 16.376 & .005 \\
\hline & DER, PBV & 11.079 & 15.490 & .255 & 9.715 & .044 \\
\hline
\end{tabular}

Note: a. Dependent Variable: EARNING PER SHARE (EPS) (Y).

Hypothesis testing is used to determine whether or not there is a significant effect of the Debt to Equity Ratio (DER) on Earning Per Share (EPS). The hypotheses to be tested are:

Ho: b1 = o Debt to Equity Ratio (DER) has no effect on EPS.

H1: $b 1 \neq$ o Debt to Equity Ratio (DER) affects EPS.

The results of the Debt to Equity Ratio (DER) regression coefficient are 3.047.

The results of the comparison of $t$ count with $t$ table obtained 3.047 greater than $t$ table 2.036. Because the value of $t$-count $>t$-table $(3.047>2.036)$ then Ho is rejected and the alternative hypothesis is accepted, meaning that partially the Debt to Equity Ratio (DER) affects Earning Per Share (EPS), t count is positive meaning that DER has a positive effect on Earning Per Share ( EPS).

\subsubsection{Testing the Hypothesis of Return on Asset (ROA) on Earning Per Share (EPS)}

The hypothesis test used to test the presence or absence of influence is the t-test. Determination of the test results (acceptance/rejection of Ho) can be done by comparing the t-count with the t-table or it can also be seen from the significant value. From the t-table, the t-table value for alpha $=0.05$ and degrees of freedom $(\mathrm{DB})=35-2$ $1=32$ on the two-party test is 2.036 . The results of the t-test can be seen in Table 5 .

Table-6. Results of t-test X2 X3 on Y.

\begin{tabular}{|c|c|c|c|c|c|c|}
\hline & \multirow{2}{*}{ Model } & \multicolumn{2}{|c|}{ Unstandardized Coefficients } & \multirow{2}{*}{$\begin{array}{c}\text { Standardized Coefficients } \\
\text { Beta }\end{array}$} & \multirow[t]{2}{*}{ t } & \multirow[t]{2}{*}{ Sig } \\
\hline & & B & Std. Error & & & \\
\hline \multirow{4}{*}{1} & (Constant) & 160.338 & 139.370 & & 1.150 & .000 \\
\hline & $\mathrm{ROA}$ & 41.772 & 21.743 & .754 & 3.921 & .064 \\
\hline & PBV & 23.441 & 26.552 & .160 & 2.883 & .003 \\
\hline & $\mathrm{ROA}, \mathrm{PBV}$ & 2.367 & 2.372 & .408 & 2.998 & .001 \\
\hline
\end{tabular}

Note: a. Dependent Variable: EARNING PER SHARE (EPS) (Y)

Hypothesis testing is used to determine whether or not there is a significant effect of Return On Assets (ROA) on Earning Per Share (EPS). The hypotheses to be tested are:

Ho: $b 1=O$ Return On Asset (ROA) has no effect on EPS

H1: $b 1 \neq 0$ Return On Asset (ROA) affects EPS

The result of the regression coefficient of Return on Assets (ROA) is 3,921.

The results of the comparison between $t$ count and $t$ table obtained 3,921 greater than $t$ table 2,036. Because the value of $t$ count $>t$ table $(3,921>2,036)$ then Ho is rejected and the alternative hypothesis is accepted, meaning that partially Return on Asset (ROA) affects Earning Per Share (EPS), t count is positive meaning Return on Asset (ROA) has a positive effect on Earning Per Share (EPS).

\subsubsection{Hypothesis Testing Firm Value (PBV) Moderates the Effect of Debt to Equity Ratio (DER) on Earning Per} Share (EPS)

Hypothesis testing is used to determine whether or not there is a moderating effect on the relationship between $\mathrm{X} 1$ and $\mathrm{Y}$. The hypotheses to be tested are:

Ho: b3 = o Firm Value $(P B V)$ does not moderate the effect of Debt to Equity Ratio (DER) on Earning Per Share (EPS).

H1: b3 $\neq$ o Firm Value (PBV) moderates the effect of Debt to Equity Ratio (DER) on Earning Per Share (EPS).

The t-test results for the interaction regression coefficient of Debt to Equity Ratio (DER) and Firm Value (PBV) (X1X4) were 9,715 with a significant of 0.044.

The results of the comparison between $t$ and table, it is obtained that the $t$ value of 9.715 is greater than $t$ table of 2.036 and the significant value of $\mathrm{X} 1 \mathrm{X} 3$ of 0.044 is smaller than alpha $=0.05$, so the conclusion is that the Ho test is rejected and the alternative hypothesis is accepted. This shows that Firm Value (PBV) moderates the relationship between Debt to Equity Ratio (DER) and Earning Per Share (EPS). 


\subsubsection{Hypothesis Testing Firm Value (PBV) Moderates the Effect of Return On Assets (ROA) on Earning Per} Share (EPS)

Hypothesis testing is used to determine whether or not there is a moderating effect on the relationship between $\mathrm{X} 2$ and $\mathrm{Y}$. The hypotheses to be tested are:

HO: $63=$ o Firm Value (PBV) does not moderate the effect of Return On Assets (ROA) on Earning Per Share (EPS).

H1: $b 3 \neq 0$ Firm Value (PBV) moderates the effect of Return On Assets (ROA) on Earning Per Share (EPS).

The t-test result for the regression coefficient of the interaction between Return On Asset (ROA) and Firm Value (PBV) (X2X3) is 2.998 with a significant of 0.001.

The results of the comparison between $t$ and table, it is obtained that the $t$ value of 2.998 is greater than $t$ table of 2.036 and the significant value of $\mathrm{X} 2 \mathrm{X} 3$ of 0.001 is smaller than alpha $=0.05$, so the conclusion is that the Ho test is rejected and the alternative hypothesis is accepted. This shows that Firm Value (PBV) moderates the relationship between Return On Asset (ROA) and Earning Per Share (EPS).

\section{Discussion}

5.1. Effect of Debt to Equity Ratio (DER) on Earning per Share (EPS)

The first hypothesis results, Debt to Equity Ratio (DER) has a significant effect on Earning Per Share (EPS). Then the Debt to Equity Ratio (DER) (X1) regression coefficient also has a positive sign which means that the higher the Debt to Equity Ratio (DER), the higher the Earning Per Share (EPS). This is supported by the calculation that the t-count value of 2.988 is greater than the t-table of 2.036. Because the value of $t$-count $>t$-table (3.047> 2.036), Ho is rejected and the alternative hypothesis is accepted, meaning that partially the Debt to Equity Ratio (DER) affects Earning Per Share (EPS). T-count is positive means that DER has a positive effect on Earning Per Share (EPS).

\subsection{The effect of Return on Asset (ROA) on Earning per Share (EPS)}

The second hypothesis test used to test whether there is an effect is a t-test. Determination of the test results (acceptance/rejection of $\mathrm{Ho}$ ) can be done by comparing the t-count with the t-table or it can also be seen from the significant value. From the t-table, the t-table value for alpha $=0.05$ and degrees of freedom $(\mathrm{DB})=35-2-1=32$ on the two-party test is 2.036. The results of the comparison between $t$ count and t table obtained 3,921 greater than $t$ table 2,036. Because the value of t-count $>\mathrm{t}$-table $(3,921>2,036)$, Ho is rejected and the alternative hypothesis is accepted, meaning that partially Return On Asset (ROA) affects Earning Per Share (EPS). t count is positive means that Return on Assets (ROA) has a positive effect on Earning Per Share (EPS).

\subsection{The Effect of Firm Value (PBV) Moderates the Effect of Debt to Equity Ratio (DER) on Earning Per Share (EPS)}

The third hypothesis test is used to determine whether or not there is an effect of Moderation on the relationship between $\mathrm{X}_{1}$ and $\mathrm{Y}$. The results of the t-test for the interaction regression coefficient of Debt to Equity Ratio (DER) and Firm Value (PBV) (X1X4) from table 4.50 are 9,715 with a significant of 0.044. The results of the comparison between $t$ and $t$ table, it is obtained that the $t$ value of 9.715 is greater than $t$ table of 2.036 and the significant value of $\mathrm{X} 1 \mathrm{X} 3$ of 0.044 is smaller than alpha $=0.05$, so the conclusion is that the Ho test is rejected and the alternative hypothesis is accepted. This shows that Firm Value (PBV) moderates the relationship of Debt to Equity Ratio (DER) to Earning Per Share (EPS).

\subsection{The Influence of Firm Value (PBV) Moderates the Effect of Return on Assets (ROA) on Earning Per Share (EPS)}

Hypothesis testing is used to determine whether or not there is a Moderating effect on the relationship between $\mathrm{X}_{2}$ and $\mathrm{Y}$. The results of the comparison between $t$ and $t$ table show that the $t$ value of 2.998 is greater than $t$ table of 2.036 and the significant value of $\mathrm{X} 2 \mathrm{X} 3$ of 0.001 is smaller than alpha $=0.05$, it is obtained the conclusion of the Ho test is rejected and the alternative hypothesis is accepted. This shows that Firm Value (PBV) moderates the relationship between Return On Asset (ROA) and Earning Per Share (EPS).

\section{Conclusions and Suggestion}

\subsection{Conclusion}

This research was conducted to determine the effect of Debt To Equity Ratio and Return On Assets on Earning Per Share with Firm Value as a Moderation Variable. Several conclusions can be drawn in this study, namely:

1. Debt To Equity Ratio (DER) has a significant effect on Earning Per Share. This is supported by the calculation that the $\mathrm{t}$-count value of 2.988 is greater than the $\mathrm{t}$-table of 2.036. Because the value of $\mathrm{t}$-count $>\mathrm{t}$-table (3.047> 2.036), Ho is rejected and the alternative hypothesis is accepted, meaning that partially the Debt to Equity Ratio (DER) affects Earning Per Share (EPS). T-count is positive means that DER has a positive effect on Earning Per Share (EPS).

2. Return On Asset (ROA) affects Earning Per Share (EPS). It can be seen that the results of the comparison between t-count and t-table obtained 3,921 greater than t-table 2,036. Because the value of $\mathrm{t}$-count> t-table $(3,921>2,036)$, Ho is rejected and the alternative hypothesis is accepted, meaning that partially Return On Asset (ROA) affects Earning Per Share (EPS). T-count is positive means that Return on Assets (ROA) has a positive effect on Earning Per Share (EPS).

3. Price to Book Value (PBV) as a moderating variable is proven to be able to strengthen the effect of Debt to Equity Ratio (DER) on Earning Per Share. This effect can be seen from the results of the t-test where the tcount value of 9.715 is greater than t-table 2.036 and the significant value of $\mathrm{X}_{1} \mathrm{X} 3$ is 0.044 less than alpha $=$ 0.05 , so the conclusion is that the Ho test is rejected and the alternative hypothesis is accepted. This shows that 
Price to Book Value (PBV) moderates the relationship of Debt to Equity Ratio (DER) to Earning Per Share (EPS).

4. Price to Book Value (PBV) as a moderating variable is proven to be able to strengthen the effect of Return On Assets (ROA) on Earning Per Share (EPS). This influence can be seen by the results of the comparison of tcount with $t$ table, it is obtained that the $t$ value of 2.998 is greater than $t$ table of 2.036 and the significant value of $\mathrm{X} 2 \mathrm{X} 3$ of 0.001 is smaller than alpha $=0.05$, so the conclusion is that the Ho test is rejected and the alternative hypothesis is accepted. This shows that Price to Book Value (PBV) moderates the relationship between Return on Asset (ROA) and Earning per Share (EPS).

\subsection{Suggestion}

Based on the description above, the suggestions that the author can put forth here are as follows:

1. Investors in making decisions to buy shares in the capital market should pay more attention to fundamental variables, especially the Debt To Equity Ratio (DER) and Return On Asset (ROA) variables because these variables have a significant effect on Earning Per Share (EPS). Apart from that, investors should also consider external factors such as exchange rates, because this will indirectly affect the profits earned in investing.

2. Companies listed on the Indonesia Stock Exchange (IDX) are expected to improve company performance each year and provide real and complete financial reports to attract investors, thereby making it easier to obtain capital from outside the company.

3. For further researchers, it is better to use a broader object, not only for various industrial sub-sector manufacturing companies that are listed on the Indonesia Stock Exchange but also in other companies. Further researchers also need to add a longer research period and add one or two variables that affect Earning Per Share so that the results can be more precise and accurate.

\section{References}

Brigham, E. F., \& Houston, J. F. (2010). Fundamentals offinancial management (1 1 th ed.). Jakarta: Salemba Empat. Darmadji, T., \& Fakhruddin. (2012). Capital market in Indonesia (3rd ed.). Jakarta: Four Salemba.

Darsono, \& Ashari. (2010). Practical guidelines for understanding financial statements. Yogyakarta: Publisher Andi.

Fahmi. (2015). Introduction to financial management (4th ed.). Bandung: Alfabeta.

Fahmi, I. (2012). Financial performance analysis. Bandung: Alfabeta.

Fahmi, I. (2011). Accounting report analysis. Bandung: Alfabeta.

Horne, J. C. V., \& Wachowicz, J. J. M. (2012). Principles of financial management (13th ed.). Jakarta: Salemba Empat.

Kasmir. (2014). Financial statement analysis (1 st ed.). Jakarta: PT. Rajagrafindo Persada.

Kasmir. (2016). Financial statement analysis. Jakarta: Raja Grafindo Persada.

Kasmir. (2012). Financial statement analysis. Jakarta: PT. Raja Grafindo Persada.

Kukuh. (2015). Effect of earning per share, capital structure, return on equity and company size on firm value in manufacturing companies listed on the Indonesia stock exchange. Essay. Thesis. Yogyakarta State University.

Lukman, \& Solihin. (2018). The effect of economic Value added, financial leverage and profitability on the stock price of PT. Summarecon Agung Tbk. Journal of Economics. Faculty of Economics. Brobodur University Jakarta, 20(2), 147-159.

Mardiasari, N. (2012). The effect of return on assets on company value with good corporate governance as a moderating variable. Thesis. Yogyakarta Islamic University.

Mardiyanti. (2012). The effect of dividend policy, debt policy and profitability on the value of manufacturing firms. Indonesian Science Management Research Journal, 3(1), 1-17.

Perdana, S. (2012). The effect of long-term debt policy and dividend policy on firm value, scientific article. Surabaya: Perbanas College of Economics. Rahardjo, B. (2009). Basics of fundamental analysis of company financial statements: Gajah Mada University Press.

Retnowati, N. (2012). Compensation management. Bandung: Karya Putra Darwati.

Simatupang, M. (2010). Practical knowledge of stock investments and mutual funds. Jakarta: Media Discourse Partners.

Sugiyono. (2009). Quantitative research methods, qualitative and $R \& D$ D. Bandung: Alfabeta.

Tandelilin, E. (2010). Portfolios and investments: Theory and applications (1 st ed.). Yogyakarta: Kanisius.

Watung, R., \& Ilat, V. (2015). The effect of return on assets (Roa), net profit margin (Npm), and earning per share (Eps) on stock prices in banking companies on the Indonesian stock exchange 2011-2015. EMBA Journal, 4(2), 518-529.

Citation Citra Larasati; Abdul Rivai; Suharto (2020). Effect of Debt to Equity Ratio and Return on Assets on Earnings per Share with Firm Value as a Moderating Variable in Various Industrial SubSector Manufacturing Companies Indonesia. Asian Business Research Journal, 5: 39-47.

\section{History:}

Received: 3 August 2020

Revised: 9 September 2020

Accepted: 24 September 2020

Published: 5 October 2020

Licensed: This work is licensed under a Creative Commons

Attribution 3.0 License (cc)

Publisher: Eastern Centre of Science and Education
Acknowledgement: All authors contributed equally to the conception and design of the study.

Funding: This study received no specific financial support.

Competing Interests: The authors declare that they have no competing interests.

interests. Transparency: The authors confirm that the manuscript is an honest accurate, and transparent account of the study was reported; that no vital
features of the study have been omitted; and that any discrepancies from the study as planned have been explained.

Ethical: This study follows all ethical practices during writing.

Eastern Centre of Science and Education is not responsible or answerable for any loss, damage or liability, etc. caused in relation to/arising out of the use of the content. Any queries should be directed to the corresponding author of the article. 